\title{
Pharmacological properties of marine macroalgae-associated heterotrophic bacteria
}

\author{
Vinaya Kizhakkepatt Kizhakkekalam ${ }^{1,2} \cdot$ Kajal Chakraborty $^{1}$
}

Received: 24 April 2018 / Revised: 28 August 2018 / Accepted: 28 October 2018 / Published online: 7 November 2018

(c) Springer-Verlag GmbH Germany, part of Springer Nature 2018

\begin{abstract}
The rich diversity of marine macroalgae and their associated bacterial flora represent a potential reservoir of bioactive compounds with valuable biotechnological and pharmaceutical use. Heterotrophic bacteria associated with the intertidal macroalgae were isolated and evaluated for their pharmacological properties using various in vitro models. Among 148 cultivable isolates, more than $50 \%$ were dominated by $\gamma$-Proteobacteria and Firmicutes, wherein 53 of them showed consistent antibacterial activity against a broad spectrum of clinically significant pathogens. The bacteria were characterized by extensive microbiological, molecular and chemical identification tools. The heterotrophs Bacillus amyloliquefaciens MTCC 12716 and Shewanella algae MTCC 12715 isolated from a red marine macroalga Hypnea valentiae exhibited potential anti-infective properties against multidrug-resistant pathogens, such as methicillin-resistant Staphylococcus aureus and vancomycin-resistant Enterococcus faecalis (minimum inhibitory concentration of $6.25-12.5 \mu \mathrm{g} / \mathrm{mL}$ ). The organic extract of $B$. amyloliquefaciens displayed significantly greater antioxidative properties $\left(\mathrm{IC}_{90}<1 \mathrm{mg} / \mathrm{mL}\right)$ and the activities showed considerable positive correlation $\left(r^{2}>0.8, P<0.05\right)$ with the inhibitory activities against angiotensin converting enzyme-I, pro-inflammatory cyclooxygenases and 5-lipoxygenase, dipeptidyl peptidase-4 and hydroxymethylglutaryl coenzyme A reductase, which were associated with hypertension, inflammation, diabetes, and hypercholesterolemia, respectively. The applications of nuclear magnetic resonance-based fingerprinting to analyze the characteristic signals in the solvent extracts and to correlate them with the pharmaceutical properties were underlined. The heterotrophic bacterium B. amyloliquefaciens MTCC 12716 might, therefore, serve as a potential therapeutic candidate to develop products with wide pharmaceutical applications.
\end{abstract}

Keyword Intertidal marine macroalgae $\cdot$ Heterotrophic bacteria · Firmicutes $\cdot$ Bacillus amyloliquefaciens MTCC 12716 . Antibacterial $\cdot$ Pharmacological properties $\cdot$ Nuclear magnetic resonance-based fingerprinting

\section{Introduction}

Communicated by Erko Stackebrandt.

Vinaya Kizhakkepatt Kizhakkekalam and Kajal Chakraborty contributed equally.

Electronic supplementary material The online version of this article (https://doi.org/10.1007/s00203-018-1592-1) contains supplementary material, which is available to authorized users.

Kajal Chakraborty

kajal.chakraborty@icar.gov.in; kajal_cmfri@yahoo.com

1 Central Marine Fisheries Research Institute, Ernakulam North, P.B. No. 1603, Cochin, Kerala State, India

2 Faculty of Marine Sciences, Lakeside Campus, Cochin University of Science and Technology, Cochin, Kerala State, India
Marine microbial heterotrophic symbionts were recognized for their capacity in imparting biochemical defences to the host eukaryotes to fight with competitive predators and pathogenic colonizers (Paul et al. 2011). These symbionts were reported to be endowed with potential bioactivities against pathogenic bacteria, inflammation, and cancer, to mention a few, and therefore, are valuable resources for drug discovery (Molinski et al. 2009). Recent research efforts established that, most often, the microbial symbionts are the sources of bioactivities associated with the host-eukaryotic symbiotic association, and apparently not the eukaryotic hosts ( $\mathrm{Li}$ and Vederas 2009).

The fraction of bioactive bacteria in association with invertebrates $(20 \%)$ and marine macroalgae $(11 \%)$ was 
described to be greater than those isolated from the surface seawater (more than 6\%) and sediments ( 5\%) (Li and Vederas 2009) although lesser than 5\% of them were cultivable under laboratory conditions. This directed to the conclusion that marine microbes have been uncultivable, and therefore, received meager attention to the scientists. However, recent research efforts proved that selected marine microorganisms could be cultivated successfully (Davidson 1995). Bacterial and fungal association were reported from the internal tissues of invertebrates and marine plant surfaces, whereas the symbionts harbored promising pharmaceutical properties (Webster and Taylor 2012). Bacterial groups, such as Firmicutes, Bacteroidetes and $\gamma$-Proteobacteria were predominantly present in association with marine macroalga Laminaria saccharina (Wiese et al. 2009). Among these, $\boldsymbol{\gamma}$-Proteobacteria was found to be the predominant cultivable class in the Haliclona simulans sponge-associated heterotrophs (Kennedy et al. 2009) and marine macroalga Jania rubens associated (greater than 70\%) microbes (Ali et al. 2012). As a sessile primary producer, marine macroalgae were reported to host wide varieties of microbes on its surface compared to other marine eukaryotes (Hollants et al. 2012). The comparative simplicity of culturing these bacteria, equated to other microbes that release bioactive metabolites, suggested that the macroalgae-associated bacteria might be useful in biotechnological applications, especially as the potential source of antimicrobial agents (Armstrong et al. 2001).

Microorganisms were recognized as valuable biological resources of chemically as well as biologically diverse compounds, whereas their potential capabilities to biosynthesize complex chemical entities from common nutrients in fermentation media have made them promising for the extensive use in the production of pharmaceutical preparations. More than 120 formulations of microbial origin are currently in clinical use for the treatment of cancer and infectious diseases, and as immune suppressors to aid organ transplantation (National Research Council 1999). They have also been demonstrated to possess varied properties of potential therapeutic applications, such as antioxidant (Tabbene et al. 2012), anti-diabetic adjuvant (Okamura et al. 1992), anti-inflammatory formulations (Tang et al. 2010), etc. Among different phyla of marine bacteria, Firmicutes and $\gamma$-Proteobacteria were recognized as important sources of bioactivities with potential pharmacological significance (Lachnit et al. 2011; Thilakan et al. 2016).

Earlier reports on macroalgae-associated bacteria contemplated their potential as antibacterial pharmacophores for use against human pathogenic microorganisms (Chakraborty et al. 2017a, b). As an ongoing programme to isolate and characterize marine macroalgae-associated symbionts, the present work has been directed to a culturedependent method to isolate heterotrophic Firmicutes and $\gamma$-Proteobacteria associated with the intertidal marine macroalgae, and evaluate for their pharmacological properties using various in vitro models. The bacteria were characterized by extensive microbiological, biotechnological and chemical identification tools. Based on the anti-infective potential against clinically significant pathogens, the heterotrophic B. amyloliquefaciens MTCC 12716 and S. algae MTCC 12715 were used to prepare organic extracts, and that were assayed for their antioxidant potential along with their abilities to inhibit various pharmacological targets, such as angiotensin converting inhibitory enzyme-1 (ACE1), pro-inflammatory cyclooxygenases and lipoxygenase (COX-1, 2 and 5-LOX), dipeptidyl peptidase-4 (DPP-4) and hydroxymethyl glutaryl coenzyme A reductase (hMGCR) associated with hypertension, inflammation, diabetes and hypercholesterolemia, respectively. The ${ }^{1} \mathrm{H}$ NMR and ${ }^{13} \mathrm{C}$ NMR-based chemical fingerprint analyses of the prominent functionalities in the organic extracts of the heterotrophs were determined to underline the significance of electronrich unsaturated centers towards the bioactive properties.

\section{Materials and methods}

\section{Isolation of marine macroalgae-associated heterotrophs}

The marine macroalgae referred to the classes of Rhodophyceae, Phaeophyceae and Chlorophyceae, were collected from the intertidal zone by hand, at low tide. The samples were collected from the coastal area of Mandapam situated at $9^{\circ} 17^{\prime} 0^{\prime \prime}$ North, $79^{\circ} 7^{\prime} 0^{\prime \prime}$ East, Gulf of Mannar region and Vizhinjam harbor located at $8.3932^{\circ}$ North, $77.0046^{\circ}$ East, in the Arabian Sea, at the Southern Coast of Peninsular India. The macroalgal samples were placed in a sterile polythene bag filled with seawater and were kept in the dark at $4{ }^{\circ} \mathrm{C}$ until further processing in the laboratory. Symbiotic heterotrophic bacteria associated with the marine macroalga Hypnea valentiae were isolated and purified by following previous reports of literature (Quevrain et al. 2014; Thilakan et al. 2016).

Briefly, the specimen samples (10 g) were thoroughly washed in sterile distilled water to remove loosely attached microbes and filth. Further, they were suspended in sterile seawater $(10 \mathrm{~mL})$ and homogenized using a pestle and mortar in a laminar airflow hood under an aseptic condition. The suspension was serially diluted in sterile seawater $(9 \mathrm{~mL})$, and different dilutions were plated on the isolation medium of Zobell Marine Agar, which was supplemented with sodium chloride $(\mathrm{NaCl}, 1 \% \mathrm{w} / \mathrm{v})$. The incubation was performed in the dark at $30{ }^{\circ} \mathrm{C}$ for 7 days. The pure colonies were obtained by subsequent isolation and purification steps on Zobell Marine Agar medium supplemented with $\mathrm{NaCl}$ $(1 \% \mathrm{w} / \mathrm{v})$ (Wiese et al. 2009; Chakraborty et al. 2014). Streak 
plate method was used to isolate an axenic culture. The bacteria isolated were then classified based on morphology and identified with biochemical tests, $16 \mathrm{~S}$ rRNA fingerprinting followed by MALDI-TOF biotyping as discussed in the following section. The growth and bioactivity of the strains used in this study were optimized under various nutritional parameters, whereas an optimized media (modified basal salt agar) was used for the biomass production based on the study. The isolates were subjected to primary screening for their antibacterial potentials. The producer strains were maintained in the same media at $20^{\circ} \mathrm{C}$ and found to be consistently active. Further, the most active strains were selected and their soluble secondary metabolites were extracted and bioactivities were analyzed against different disease models.

\section{Primary antibacterial screening for active strains}

Antibacterial properties of the heterotrophic isolates was examined by spot on the lawn assay (Chakraborty et al. 2014). In brief, a lawn of the pathogenic bacteria was made to grow on Mueller-Hinton agar plates, over which the isolates at its late log phase were spotted in an aseptic condition. The test pathogenic organisms, such as Escherichia coli (MTCC 443), Streptococcus pyogenes (MTCC 1924), and Edwardsiella tarda (MTCC 2400) were obtained from the National Centre for Aquatic Animal Health-(NCAAH) of Cochin University of Science and Technology (CUSAT), Cochin. Pathogenic Vibrio parahaemolyticus (MTCC 451) was obtained from the Microbial Type Culture Collection and Gene Bank (MTCC) of Institute of Microbial Technology (Chandigarh, India), an affiliate member of the World Federation for Culture Collections (WFCC) and recognized as an International Depository Authority (IDA). These cultures were maintained in our laboratory, and multidrug-resistant pathogens including methicillin-resistant Staphylococcus aureus (ATCC 33592) and vancomycin-resistant Enterococcus faecalis (ATCC 51299) were procured from the American Type Culture Collection (Manassas, VA, USA). The pathogens were procured during the period of 2016, and their pathogenicities were assessed by performing PCR amplification with specific virulent factors for each pathogenic bacterium, immediately after obtaining the cultures. Their identities were confirmed by specific phenotypic and genotypic characterization, such as microbiological and biochemical testing, followed by $16 \mathrm{~S}$ rRNA sequence similarity check (Armstrong et al. 2001). The pathogenic strains were maintained in Brain heart infusion agar and Nutrient agar supplemented with $\mathrm{NaCl}$ as per manufacturers' protocol.

The antibacterial activities were recorded according to the inhibition zone developed on the plates after a period of 48 -h incubation at $30^{\circ} \mathrm{C}$. Further, the crude extracts of selected strains were assessed by Minimum Inhibitory Concentration (MIC) by broth microdilution assay according to the National Committee for Clinical Laboratory Standards (NCCLS, 2004) with minor modifications. The MIC was determined by means of serial dilutions of the extracts (Balouiri et al. 2016) and positive control (chloramphenicol). The test samples of $100 \mu \mathrm{L}$ were serially diluted in multi-well assay plates, whereas the pathogenic bacterial broth $\left(100 \mu \mathrm{L}, 2 \times 10^{6}\right.$ cell $\left./ \mathrm{mL}\right)$ was added separately. The plate was then incubated for $24 \mathrm{~h}$ at $37^{\circ} \mathrm{C}$, and the minimum concentration of the sample, which inhibit the growth of the pathogen, where the $\mathrm{OD}_{600}$ of the well was near to or equal to zero, has been considered as the MIC. Further, the bactericidal property of the samples was affirmed by observing the plates after the addition of tetrazolium salt of 3-(4, 5-dimethylthiazol-2-yl)-2, 5-diphenyltetrazolium bromide (MTT) to the wells.

\section{Identification of the active isolates}

The antagonistic bacteria were identified phenotypically, supported by the biochemical methods (Krieg and Holt 1984), Matrix Assisted Laser Desorption/Ionization-Time of Flight Mass Spectrometry (MALDI-TOF MS), followed by $16 \mathrm{~S}$ rRNA sequencing (Armstrong et al. 2001) and analysis of bacterial membrane fatty acid (Zhu et al. 2005). Mass spectroscopic experiments were performed on a MALDI-TOF MS spectrometer (Microflex, BrukerDaltonics, Germany) operating in a linear positive mode. Mass spectra were evaluated between the $\mathrm{m} / \mathrm{z}$ range of 2000 to 20,000, and analyzed by the MALDI Biotyper (version 3.1) for strain identification. Briefly, the bacterial proteins were extracted with ethanol/formic acid extraction method, whereas $1 \mu \mathrm{L}$ of the extract was spotted on the target plate, and allowed to dry before being covered with $1 \mu \mathrm{L}$ of $\alpha$-cyano-4-hydroxycinnamic acid. The cutoff score for similarity search was $\geq 1.7$ for species-level, and any score lesser than this was considered as an unreliable identification. The isolates showing significant inhibitory activity were selected and phenol-chloroform extraction method was adopted for isolating DNA from the active strains. Further, the qualities of DNA samples were detected by agarose gel electrophoresis and their concentrations were evaluated using a Biophotometer (Applied Biosystems, USA). Universal primers AGAGTTTGATCC TGGCTCAG (forward) and ACGGCTACCTTGTTACGA CTT (reverse) (Weisburg et al. 1991) were employed to amplify the 16S rRNA gene. Further, the PCR products were sequenced and deposited in the NCBI GenBank.

\section{Assessment of pathogenicity}

Pathogenicity of the selected microorganisms was studied by hemolytic assay (Gao et al. 2000) on sheep blood agar 
plates. Briefly, blood agar with 5\% defibrinated sheep blood was dispensed into a sterile Petri-plate aseptically. Overnight grown cultures of the bacteria were spot inoculated at the center of the plates and incubated at $30^{\circ} \mathrm{C}$ for $18-24 \mathrm{~h}$. Streptococcus pyogenes MTCC 1924 was used as the control organism.

\section{Preparation of crude extracts and in vitro bioassays}

The extracellular metabolites of the potentially antagonistic bacteria B. amyloliquefaciens (MTCC 12716) and S. algae (MTCC 12715) were extracted with a suitable organic solvent. In brief, the bacteria were surface cultured over nutrient agar in the dark at $30^{\circ} \mathrm{C}$ for $72 \mathrm{~h}$ in the case of $S$. algae, and $48 \mathrm{~h}$ for B. amyloliquefaciens. After the incubation period, the culture on the surface was removed, and the agar with the extracellular metabolites was exhaustively extracted by refluxing with solvent ethyl acetate on a temperature-controlled water bath before being concentrated in vacuo on a rotary vacuum evaporator (Heidolph, Schwabach, Germany). The ethyl acetate extract (470 g) of the antagonistic bacteria were assayed in vitro for their antioxidant potential along with their abilities to inhibit various pharmacological disease targets, such as angiotensin converting enzyme-1 (ACE-1), pro-inflammatory cyclooxygenases and lipoxygenase (COX-1, 2 and 5-LOX), dipeptidyl peptidase-4 (DPP-4), and hydroxymethyl glutaryl coenzyme A reductase (hMGCR) associated with hypertension, inflammation, diabetes and hypercholesterolemia, respectively.

\section{Antioxidant activity}

Antioxidant activities of the crude extracts were evaluated by 1,1-diphenyl-2-picrylhydrazyl (DPPH) and 2, 2-azinobis (3-ethyl-benzothiazoline-6-sulfonic acid) (ABTS) free radical scavenging abilities. The measurement of DPPH radical scavenging activity was performed by a previously described method (Brand-Williams et al. 1995). The changes in color were read at an absorbance of $517 \mathrm{~nm}$ after $20 \mathrm{~min}$ of reaction by a UV-VIS spectrophotometer (Varian Cary, USA). ABTS $^{+}$assay was carried out by an established method of Re et al. (1999). The reaction mix was kept for $6 \mathrm{~min}$, and the absorbance was recorded at $734 \mathrm{~nm}$. DPPH/ ABTS scavenging activities (in percentage) were expressed as $\left(A_{\mathrm{C}}-A_{\mathrm{S}}\right) / A_{\mathrm{C}} \times 100$, where $\mathrm{A}_{\mathrm{C}}$ represented the absorbance of control and $A_{S}$ that of the sample. The scavenging activities on DPPH/ABTS ${ }^{+}$radical were documented, and the $\mathrm{IC}_{90}$ values (concentration of the bacterial crude extracts that inhibit $90 \%$ of the radical/enzyme, $\mathrm{mg} / \mathrm{mL}$ ) calculated using the non-linear regression plot. Ascorbic acid was used as the standard during the assessment of free radical scavenging activity.

\section{Anti-hypertensive activity}

Anti-hypertensive activities of the extracts were assessed based on the inhibition rate of ACE-1 (Holmquist et al. 1979). In brief, ACE-1 (20 $\mu \mathrm{L}, 1 \mathrm{U} / \mathrm{mL}$, from rabbit lung) was mixed with the crude extracts $(100 \mu \mathrm{g})$, and the mixture was added with $N$-[3-(2-furyl) acryloyl]-L-phenylalanylglycylglycine (FAPGG, $0.5 \mathrm{mM}$ ) dissolved Tris-HCl buffer (pH 7.5) supplemented with common salt. The reduction in absorbance at $345 \mathrm{~nm}$ was monitored with a multi-plate reader (Multiskan GO type 1510, Thermo Scientific, USA) within a $1.5 \mathrm{~min}$ interval at room temperature, and was stated as $\Delta_{\mathrm{Ab}}$ sample/min. Blank was set with distilled water and expressed as $\Delta_{\mathrm{Ab}}$ blank/min. Captopril was served as the positive control for ACE inhibition. The plots of ACE-1 inhibition by the extracts were recorded, and the $\mathrm{IC}_{90}$ values $(\mathrm{mg} / \mathrm{mL})$ were calculated.

\section{Anti-diabetic activity}

The crude extracts were assayed for their anti-diabetic activities by inhibition of $\alpha$-glucosidase, $\alpha$-amylase, and DPP- 4 (dipeptidyl peptidase-4) enzymes. The $\alpha$-amylase and $\alpha$-glucosidase inhibitory activities of the studied extracts were measured by the standard method (Ademiluyi and Oboh 2013) with suitable alteration. The absorbance of the reaction mixture was measured at 540 and $405 \mathrm{~nm}$, respectively, whereas acarbose was used as a standard. For the inhibition of DPP-4, the extracts were made in different strengths in Tris- $\mathrm{HCl}$ buffer $(0.05 \mathrm{M}, \mathrm{pH} 7.5)$. The substrate (gly-pro- $p$-nitroanilide) was added to the reaction mixture before an incubation period of $30 \mathrm{~min}$ at $37^{\circ} \mathrm{C}$. Glacial acetic acid (25\%) was added to quench the reaction, and the absorbance was recorded at $450 \mathrm{~nm}$, whereas diprotein-A (Ile-Pro-Ile) was used as a reference.

\section{Anti-inflammatory and anti-hypercholesterolemic activities}

Dual blocking of both cyclooxygenases (COX-1 and COX-2) and 5-lipoxygenase (5-LOX) is a commonly used method for the treatment of inflammatory diseases without causing severe side effects (Charlier and Michaux 2003). The in vitro COX (Larsen et al. 1996) and 5-LOX inhibition assays (Baylac and Racine 2003) were used to determine the anti-inflammatory activities of the bacterial extracts. The 3-hydroxy3-methyl-glutaryl-coenzyme A (hMG-CoA) reductase enzyme inhibition by crude $B$. amyloliquefaciens and $S$. algae extracts was evaluated with hMG-CoA reductase (hMGCR) assay kit from Sigma-Aldrich (St. Louis, MO, USA) to assess their anti-hypercholesterolemic activities. In brief, the crude organic extracts were added with the reaction mixture containing nicotinamide adenine dinucleotide 
phosphate $(0.4 \mathrm{mM})$ and $\mathrm{hMG}-\mathrm{CoA}(0.4 \mathrm{mM})$ in a final volume of $0.2 \mathrm{~mL}$ of potassium phosphate buffer $(0.1 \mathrm{M}$, pH 7.4) containing $\mathrm{KCl}(0.12 \mathrm{M})$, ethylenediaminetetraacetic acid (1 $\mathrm{mM})$, and dithiothreitol $(5 \mathrm{mM})$, before being added with HMG-CoA reductase (human recombinant, $2 \mu \mathrm{L}$ ) and incubated at $37{ }^{\circ} \mathrm{C}$ in the multi-plate reader spectroscopic instrument (Multiskan GO, Thermo Scientific, USA) fitted out with thermostatically organized cell holder. The rates of NADPH consumption were monitored every $20 \mathrm{~s}$ for up to $15 \mathrm{~min}$ by spectral scanning at $340 \mathrm{~nm}$. Percentage inhibition of COX-1, COX-2, 5-LOX and hMGCR were calculated, and the results were expressed in $\mathrm{IC}_{90}$, the concentration at which it inhibits $90 \%$ of the enzyme activity.

\section{Spectroscopic fingerprint analyses}

Spectroscopic fingerprint characteristics of the organic extracts were comprehensively studied by Fourier transform infrared spectrometer (Perkin-Elmer Series 400 FTIR, USA) scanned between wave-numbers $4000-400 \mathrm{~cm}^{-1}$ and nuclear magnetic resonance $\left({ }^{13} \mathrm{C}\right.$ NMR and ${ }^{1} \mathrm{H}$ NMR) spectral analysis on a Bruker AVANCE III $600 \mathrm{MHz}$ spectrometer (Bruker, Germany). Chemical shift $\left(\delta_{\mathrm{H}}\right.$ or $\delta_{\mathrm{C}}$ ) values were recorded as ppm ( $\delta$, parts per million), and the protons at the definite regions of the ${ }^{1} \mathrm{H}$ NMR spectra were integrated (proton integral, $\Sigma H$ ) to determine the aggregate number of protons in characteristic regions of the spectra (Fig. 2). The ${ }^{1} \mathrm{H}-\mathrm{NMR}$ spectra were allocated into five discrete regions, such as alkane hydrocarbon (primary through tertiary, $\delta_{\mathrm{H}} 0.1-2.0$ ), allylic $\left(\mathrm{CH}_{2}=\mathrm{CH}-\mathrm{Me}\right) /$ acetyl $\{-\mathrm{C}(=\mathrm{O}) \mathrm{Me}\} /$ derivatized hydride of alkanoates $\left\{-\mathrm{CH}_{2} \mathrm{C}(=\mathrm{O}) \mathrm{O}-, \delta_{\mathrm{H}} 2.1-2.5\right\}$, methoxyl (-OMe)/functionalized alkanol $\left(-\mathrm{CH}_{2} \mathrm{OH}, \delta_{\mathrm{H}} 2.6-3.5\right)$, anomeric (due to polysaccharides, $\delta_{\mathrm{H}} 3.6-4.5$ ), olefinic $(-\mathrm{CH}=\mathrm{CH}-)$ /protons of the hydride group of alkanoates $\left\{-\mathrm{CH}_{2} \mathrm{C}(=\mathrm{O}) \mathrm{OMe}, \delta_{\mathrm{H}} 4.6-6.0\right\}$, and aryl protons $\left(\mathrm{C}_{6} \mathrm{H}_{5}-\mathrm{H}\right.$, $\delta_{\mathrm{H}}$ 6.6-8.6) (Table 1). The ${ }^{1} \mathrm{H}$ NMR trace at $\delta_{\mathrm{H}} 9-10$ characterized the aldehydic protons. The ${ }^{13} \mathrm{C}$ NMR spectral data were used to recognize the carbons attributed to alkane hydrocarbon ( $\delta_{\mathrm{C}}$ up to 40$)$, alkoxy $\left(-\mathrm{CH}_{2} \mathrm{O}-; \delta_{\mathrm{C}} 45-70\right)$, carbons of the hydride group of alkanoates $\left\{-\mathrm{CH}_{2} \mathrm{C}(=\mathrm{O}) \mathrm{OMe}\right.$, $\left.\delta_{\mathrm{C}} 75-80\right)$, functionalized olefine $\left(\delta_{\mathrm{C}} 110-140\right)$, aromatic $\left(\delta_{\mathrm{C}}\right.$ $140-160)$, ester alkanoates $\left\{-\mathrm{C}(=\mathrm{O}) \mathrm{O}-; \delta_{\mathrm{C}} 160-180\right\}$ and carbonyl (aldehydic/ketonic) moieties $\left(\delta_{\mathrm{C}} 180-210\right)$.

\section{Statistical analysis}

Statistical analysis was carried out using the SPSS software (SPSS Inc, USA, ver. 10.0). The studies were carried out in triplicate, and the means were determined for significance at 5 percent level $(P<0.05)$ by means of analysis of variance (ANOVA). The mean variances in the data set were identified with principal component analysis (PCA).

\section{Results}

\section{Isolation of marine macroalgae-associated heterotrophs and antibacterial screening}

Seven different intertidal macroalgae representing Rhodophyceae, Phaeophyceae and Chlorophyceae were collected from the intertidal zones, and that include brown algae, Sargassum myricocystum, Padina gymnospora, Turbinaria ornata, red algae Hypnea valentiae. Kappaphycus alvarezii and green algae Ulva reticulata, Caulerpa racemosa. A total number of 148 heterotrophic bacterial strains were isolated from the macroalgal species. The bacteria isolated were classified based on morphology and further with microbiological and biochemical tests, 16S rRNA fingerprinting followed by MALDI-TOF biotyping.

The bacterial classes of Gamma proteobacteria and Firmicutes represented the predominant bacterial communities comprising more than $50 \%$ of the total isolates screened. The isolated bacteria were further screened for their antibacterial activity by spot over lawn assay, and 53 of them showed consistent antibacterial activity against at least
Table 1 Nature and integral values of protons obtained from the ${ }^{1} \mathrm{H}-\mathrm{NMR}$ of the organic extracts of B. amyloliquefaciens MTCC 12716 and S. algae MTCC 12715

\begin{tabular}{|c|c|c|c|}
\hline \multicolumn{4}{|l|}{ Integral values of protons } \\
\hline Type of protons ${ }^{\mathrm{a}}$ & Chemical shift $(\underline{\delta})$ & $\begin{array}{l}\text { S. algae MTCC } \\
12715\end{array}$ & $\begin{array}{l}\text { B. amylolique- } \\
\text { faciens MTCC } \\
12716\end{array}$ \\
\hline Saturated hydrocarbons & $0.5-2.0$ & 329.7 & 152.9 \\
\hline $\begin{array}{c}-\mathrm{CH}_{2}=\mathrm{CH}-\mathrm{CH}_{3} / \mathrm{RC}(=\mathrm{O}) \mathrm{CH}_{3} / \\
\mathrm{RCH}_{2} \mathrm{C}(=\mathrm{O}) \mathrm{OR}_{1} / \mathrm{Ar}-\mathrm{CH}_{3}\end{array}$ & $2.1-2.5$ & 61.81 & 40.73 \\
\hline$-\mathrm{OCH}_{3} / \mathrm{RCH}_{2}-\mathrm{X} / \mathrm{RCH}_{2} \mathrm{OH}$ & $2.6-3.5$ & 23.94 & 22.96 \\
\hline Anomeric (due to polysaccharides) & $3.6-4.5$ & 48.02 & 64.73 \\
\hline $\mathrm{RCH}=\mathrm{CHR}_{1} / \mathrm{RCH}_{2} \mathrm{C}(=\mathrm{O}) \mathrm{OCH}_{3}$ & $4.6-6.0$ & 18.82 & 12.42 \\
\hline Ar-H & $6.6-8.6$ & 25.80 & 28.77 \\
\hline
\end{tabular}

${ }^{\mathrm{a}}$ The protons at the defined regions of the ${ }^{1} \mathrm{H}$ NMR spectra were integrated to get the number of protons in specific regions 
one test pathogen. Bactericidal activities were furthermore ascertained by MTT reaction, whereas the blue cells were indicated as live. The antibacterial activities of these heterotrophs against the pathogens were summarized in Table 2. Two of the most active cultures B. amyloliquefaciens and $S$. algae (Fig. 1), which were isolated from Hypnea valentiae were selected to study their pharmacological properties in greater details based on their superior bioactivity among other strains. The growth and bioactivities of the strains used in this study were optimized under various nutritional parameters, whereas an optimized media (modified basal salt agar) was used for the biomass production based on the study. The producer strains were maintained in the same media at $20^{\circ} \mathrm{C}$, and found to be consistently active under laboratory culture condition.

These isolates were characterized by biochemical, membrane analysis of fatty acids, 16S rRNA gene sequencing, followed by MALDI-TOF MS with a confidence score of 1.953 and 2.152 as B. amyloliquefaciens and S. algae, respectively. Among the selected bacterial strains, $B$. amyloliquefaciens belonged to Gram-positive, and S. algae was classified as Gram-negative, as determined by Gram staining and potassium hydroxide $(\mathrm{KOH})$ screening experiments. Biochemical experiments deduced $S$. algae as rodshaped, aerobic, and brown pigmented bacterium, which was able to ferment sugars to produce hydrogen sulfide on triple iron sugar (TSI) slants, whereas B. amyloliquefaciens, with the morphology of being white wavy, lobed margins, possessed casein hydrolysis and nitrate reduction properties. Blackish-brown pigmentation by $S$. algae was recorded at the late exponential phase due to the production of pyomelanin (Turick et al. 2008). Optimal growth of S. algae occurred with $\mathrm{pH} 8.0$ in the presence of $1-4 \%$ of $\mathrm{NaCl}$ at temperature $30^{\circ} \mathrm{C}$, and B. amyloliquefaciens at $37^{\circ} \mathrm{C}$ with $\mathrm{pH} 7-9$. The predominance of terminally methyl-branched iso and anteiso fatty acids with $\mathrm{C}-12$ to 17 characterized $S$. algae, whereas $\mathrm{C}_{15}$ and $\mathrm{C}_{17}$ iso/anteiso fatty acids were predominant in B. amyloliquefaciens. Among the $n-9$ fatty acids, cis-octadec-9-enoate $(\mathrm{C} 18: 1 n-9 \mathrm{c})$ was found to be present in S. algae other than cis-octadec-11-enoate $(\mathrm{C} 18: 1 n-7 \mathrm{c})$ and cis-heptadec-11-enoate (C17:1n-6c). Further, the similarity of $16 \mathrm{~S}$ rRNA sequences was tested with known sequences of $B$. amyloliquefaciens and $S$. algae using BLAST search tool, and submitted in GenBank with accession numbers of KX272634 and KX272635, respectively. These bioactive isolates were deposited in Microbial Type Culture Collection (MTCC), an International microbial depository authority in South-East Asia under the Budapest Treaty, with accession numbers of B. amyloliquefaciens MTCC 12716 and S. algae MTCC 12715, respectively.

The crude organic (ethyl acetate) extracts of $B$. amyloliquefaciens MTCC 12716 and S. algae MTCC 12715 exhibited strong antagonism against a broad spectrum of pathogenic bacteria, Escherichia coli (gastrointestinal infection), Streptococcus pyogenes (skin infection), Edwardsiella tarda (gastrointestinal infection and myonecrosis), Vibrio parahemolyticus (gastrointestinal infection), MRSA (methicillin-resistant Staphylococcus aureus) (skin infection) and VRE (vancomycin-resistant Enterococcus faecalis) (sepsis and meningitis) (Fig. 1). Inhibitory activities of the bacterial isolates were observed on MTT-sprayed Mueller Hinton agar plates. The microdilution method also displayed a significant MIC of $6.25-25 \mu \mathrm{g} / \mathrm{mL}$ against the test pathogenic bacteria (Table 2). Additionally, there was no zone

Table 2 Antibacterial activities of marine macroalgae-associated heterotrophic B. amyloliquefaciens MTCC 12716 and S. algae MTCC 12715 against pathogenic bacteria and minimum inhibitory concentrations (MICs) of their ethyl acetate extracts

\begin{tabular}{|c|c|c|c|c|}
\hline \multirow[t]{2}{*}{ Test pathogens } & \multicolumn{2}{|c|}{ B. amyloliquefaciens MTCC 12716} & \multicolumn{2}{|l|}{ S. algae MTCC 12715} \\
\hline & Inhibition zone ${ }^{\mathrm{a}}(\mathrm{mm})$ & $\begin{array}{l}\text { Crude }^{\mathrm{b}} \text { MIC } \\
(\mu \mathrm{g} / \mathrm{mL})\end{array}$ & Inhibition zone ${ }^{\mathrm{a}}(\mathrm{mm})$ & $\begin{array}{l}\mathrm{Crde}^{\mathrm{b}} \\
(\mathrm{MIC})(\mu \mathrm{g} / \\
\mathrm{mL})\end{array}$ \\
\hline Vibrio parahaemolyticus (MTCC 451) & $32^{\mathrm{a}} \pm 0.60$ & 6.25 & $27^{\mathrm{a}} \pm 0.07$ & 12.5 \\
\hline Methicillin resistant Staphylococcus aureus (ATCC 33592) & $22^{\mathrm{a}} \pm 0.60$ & 12.5 & $16^{\mathrm{b}} \pm 0.04$ & 12.5 \\
\hline Vancomycin resistant Enterococcus faecalis (ATCC 51299) & $20^{\mathrm{b}} \pm 0.37$ & 6.25 & $14^{\mathrm{b}} \pm 0.03$ & 12.5 \\
\hline Escherichia coli (MTCC 443) & $10^{\mathrm{c}} \pm 0.25$ & 12.5 & $11^{\mathrm{c}} \pm 0.05$ & 25.0 \\
\hline Edwardsiella tarda (MTCC 2400) & $21^{\mathrm{a}} \pm 0.30$ & 6.25 & $17^{\mathrm{b}} \pm 0.02$ & 6.25 \\
\hline Streptococcus pyogenes (MTCC 1924) & $10^{\mathrm{c}} \pm 0.44$ & 6.25 & $11^{\mathrm{b}} \pm 0.09$ & 12.5 \\
\hline Chloramphenicol $^{\mathrm{c}}$ & $27^{\mathrm{a}} \pm 0.30$ & 6.25 & $27^{\mathrm{a}} \pm 0.30$ & 6.25 \\
\hline
\end{tabular}

Data were expressed as mean \pm standard deviation of three replicates. Means followed by the different superscripts $(\mathrm{a}-\mathrm{c})$ within the same row indicate significant difference $(P<0.05)$

${ }^{\mathrm{a}}$ Inhibition zone diameter (in $\mathrm{mm}$ )

${ }^{\mathrm{b}}$ Minimum Inhibitory concentration $(\mu \mathrm{g} / \mathrm{mL})$ of ethyl acetate extract of the bacteria

${ }^{\mathrm{c}}$ Standard antibiotic (positive control) 
Fig. 1 a Spot over lawn assay of the cultures $B$. amyloliquefaciens MTCC 12716 (BA) and S. algae MTCC 12715 (SA) against methicillin-resistant Staphylococcus aureus (ATCC 33592). The clear zones displayed by the isolates indicated the antibacterial activity. Antagonistic activities of the isolates were recorded as the inhibition zone diameter determined as a space of $\geq 1 \mathrm{~mm}$ between the circular area (=lawn of the isolate) and the end of the clear zone bounded by the lawn of the test strain. b View of the Gram stained culture of B. amyloliquefaciens MTCC 12716. c Gram stained image of S. algae MTCC 12715. d Disc diffusion assay with the organic extracts of B. amyloliquefaciens MTCC 12716 (BA) and S. algae MTCC 12715 (SA) against VRE (vancomycin-resistant Enterococcus faecalis ATCC 51299), and e MRSA (methicillin-resistant Staphylococcus aureus ATCC 33592). The zones of antibacterial activities were denoted by the arrows
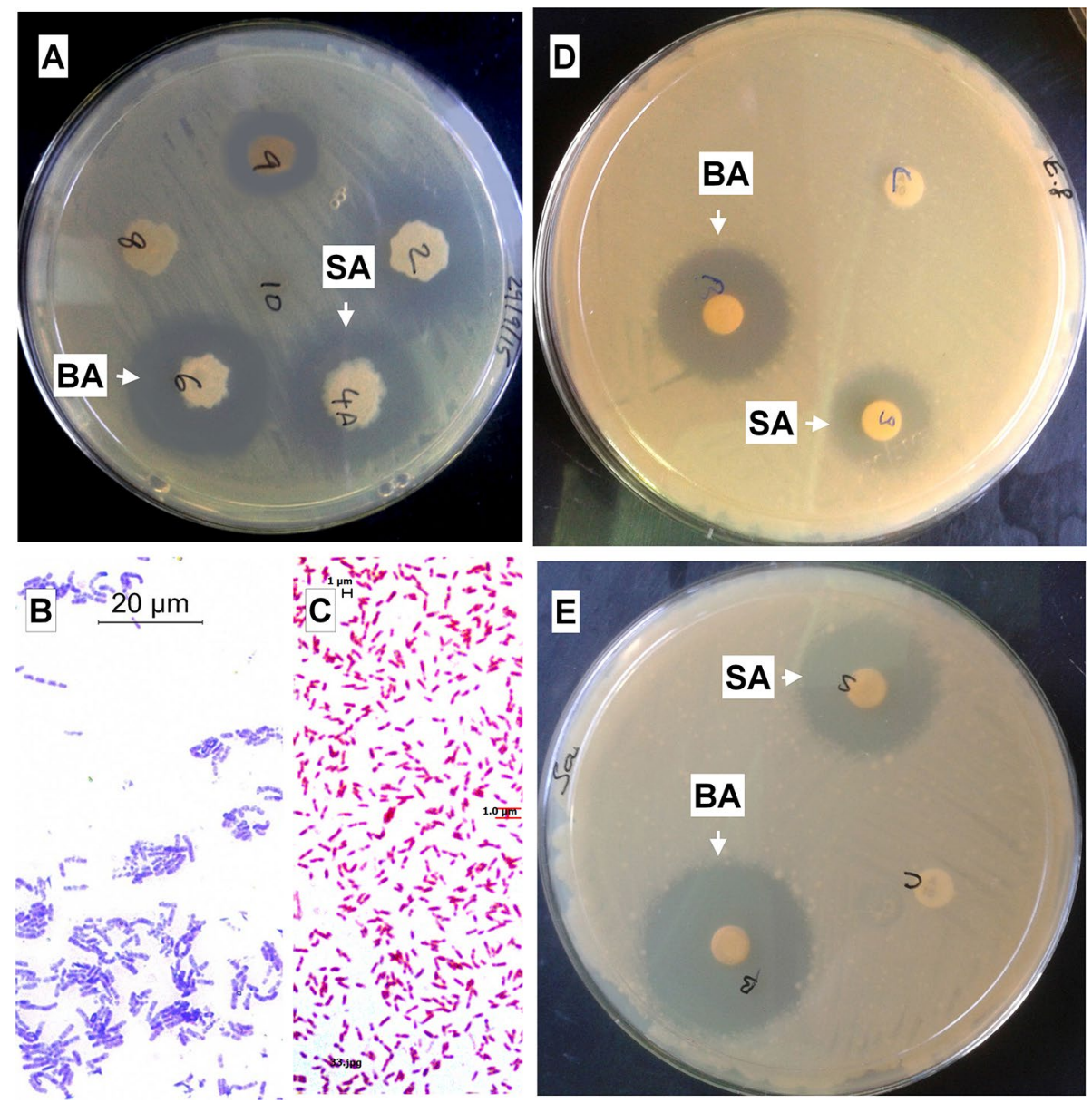

of clearance indicating hemolytic activity developed on the blood agar plates with the test organisms B. amyloliquefaciens MTCC 12716 and S. algae MTCC 12715, whereas $S$. pyogenes exhibited complete hemolysis ( $\beta$-hemolysis) around the colonies.

\section{Pharmacological activities of the extracts of $B$. amyloliquefaciens MTCC 12716 and S. algae MTCC 12715}

The solvent extracts of B. amyloliquefaciens MTCC 12716 and $S$. algae MTCC 12715 were assayed in vitro for their antioxidant potential along with their abilities to inhibit various pharmacological targets, such as ACE-1, pro-inflammatory enzymes (COX-1, 2, 5-LOX), DPP-4 and hMGCR, which were associated with hypertension, inflammation, diabetes and hypercholesterolemia, respectively. The organic extract of B. amyloliquefaciens MTCC 12716 exhibited significantly greater antioxidative potential as determined by the scavenging activities of DPPH ( $\left.\mathrm{IC}_{90} 278 \mu \mathrm{g} / \mathrm{mL}\right)$ and $\mathrm{ABTS}^{+}$ $\left(\mathrm{IC}_{90} 136 \mu \mathrm{g} / \mathrm{mL}\right.$ ) radicals compared to that obtained from $S$. algae MTCC 12715 ( $\mathrm{IC}_{90} 602$ and $483 \mu \mathrm{g} / \mathrm{mL}$, respectively). The ethyl acetate extract derived from B. amyloliquefaciens
MTCC 12716 exhibited significantly greater inhibition towards ACE-1 ( $\left.\mathrm{IC}_{90} 448 \mu \mathrm{g} / \mathrm{mL}\right)$ than that of $S$. algae MTCC $12715\left(\mathrm{IC}_{90} 638 \mu \mathrm{g} / \mathrm{mL}\right)(P<0.05)$. Likewise, the organic extracts of B. amyloliquefaciens MTCC 12716 and S. algae MTCC 12715 were found to inhibit $\alpha$-amylase and DPP-4 with $\mathrm{IC}_{90} 639-837$ and 354-769 $\mu \mathrm{g} / \mathrm{mL}$, respectively. Notably, the $\alpha$-glucosidase inhibitory potential of the organic extract from B. amyloliquefaciens MTCC 12716 (IC ${ }_{90} 84 \mu \mathrm{g}$ / $\mathrm{mL})$ and that of $S$. algae MTCC $12715\left(\mathrm{IC}_{90} 530 \mu \mathrm{g} / \mathrm{mL}\right)$ were significantly greater than the standard Acarbose $\left(\mathrm{IC}_{90}\right.$ $645 \mu \mathrm{g} / \mathrm{mL}$ ). The extracts exhibited considerable inhibition against the pro-inflammatory enzymes, which appeared to play significant functional roles in the metabolic pathway of inflammation. The organic extract from B. amyloliquefaciens MTCC 12716 and S. algae MTCC 12715 were found to be selective COX-2 and 5-LOX inhibitors (anti-COX-2 $\mathrm{IC}_{90} 29-44 \mu \mathrm{g} / \mathrm{mL}$; anti-LOX-5 $\mathrm{IC}_{90} 6.06-7.74 \mu \mathrm{g} / \mathrm{mL}$ ) than commercially available NSAID (aspirin anti-COX-2 $\mathrm{IC}_{90}$ 83-86 $\mu \mathrm{g} / \mathrm{mL}$; anti-LOX-5 IC $_{90} 79 \mu \mathrm{g} / \mathrm{mL}$ ). A dose-response in vitro analysis with regard to the inhibition of hMGCR displayed significant activity with the ethyl acetate extract of B. amyloliquefaciens MTCC $12716\left(\mathrm{IC}_{90} 17.3 \mu \mathrm{g} / \mathrm{mL}\right)$ and $S$. algae MTCC 12715 ( $\mathrm{IC}_{90} 74.6 \mu \mathrm{g} / \mathrm{mL}$ ) (Table 3). 


\section{Spectroscopic fingerprinting of the functional groups}

The labelling of carbons and protons allied with their characteristic magnetic fields of the functional groups in the ethyl acetate extracts of B. amyloliquefaciens MTCC 12716 and $S$. algae MTCC 12715 were recorded by the combined ${ }^{1} \mathrm{H}$ NMR (Fig. 2, Fig. S1-S2) and ${ }^{13} \mathrm{C}$ NMR experiments (Fig. 3, Fig. S3-S4). Aromatic proton signals $\left(\delta_{\mathrm{H}} 6.6-8.6\right)$ were recorded in the ${ }^{1} \mathrm{H}$ NMR spectral data of the bacterial extracts, whereas that extracted from $B$. amyloliquefaciens MTCC 12716 displayed the greater proton integral $\left(\sum \mathrm{H}\right)$ of about 28.77 than that recorded with S. algae MTCC 12715 extract $\left(\sum \mathrm{H} 25.80\right)$. Higher proton integrals $\left(\sum \mathrm{H} 23.94\right)$ at $\delta_{\mathrm{H}} 2.5-3.5$ (attributed to the presence of $-\mathrm{OCH}_{3} / \mathrm{RCH}_{2}$ $\mathrm{X} / \mathrm{RCH}_{2} \mathrm{OH}$ groups) were documented in the ethyl acetate extract of $S$. algae MTCC 12715. The number of protons at $\delta_{\mathrm{H}} 2-2.5$ were attributed to the acetyl or allylic functionalities, and were recorded to be higher in S. algae MTCC 12715 ( $\sum \mathrm{H} 61.81$ ), whereas comparatively weaker proton integrals at this position were noted for B. amyloliquefaciens MTCC 12716 extract ( $\left.\sum \mathrm{H} 40.73\right)$. Notably, the proton integrals at the olefinic region $\left(\delta_{\mathrm{H}} 4.5-6\right)$ of organic extract derived from $S$. algae MTCC 12715 was marginally higher ( $\left.\sum \mathrm{H} 18.82\right)$ than that recorded with $B$. amyloliquefaciens MTCC 12716 extract ( $\left.\sum \mathrm{H} 12.42\right)$. The ethyl acetate extract of S. algae MTCC 12715 displayed greater proton integral owing to saturated hydrocarbons, whereas that of $B$. amyloliquefaciens MTCC 12716 exhibited greater signals in the downfield (with a predominance of electronegative functional groups) region of the NMR spectrum. It is interesting to note the greater proton integrals at $\delta_{\mathrm{H}} 3.6-4.5\left(\sum \mathrm{H}\right.$ 64.73 , due to anomeric protons associated with polysaccharides) of organic extract due to B. amyloliquefaciens MTCC 12716, whereas comparatively weaker proton integrals at this position were noted for $S$. algae MTCC 12715 extract ( $\left.\sum \mathrm{H} 48.02\right)$.

The attributions of different types of carbons (primary through quaternary) in the EtOAc extracts of the heterotrophic bacteria were furthermore confirmed by extensive ${ }^{13} \mathrm{C}$ NMR experiments. The EtOAc extract of $S$. algae MTCC 12715 exhibited a greater number of carbon atoms assigned to the saturated hydrocarbons $\left(\delta_{\mathrm{C}}\right.$ 10-40) (Fig. 3), and the results were in accordance with the greater proton integrals of the same $\left(\sum \mathrm{H} 329.7\right)$. Likewise, a greater number of aromatic signals $\left(\delta_{\mathrm{C}} 140-160\right)$ was recognized in the EtOAc extract of B. amyloliquefaciens MTCC 12716 than that displayed by $S$. algae MTCC 12715. The distinctive peaks attributed to the carbonyl groups were recorded at $\delta_{C} 180-200$, which were abundant in the organic extract of $B$. amyloliquefaciens MTCC 12716, whereas meager traces of these highly
Table 3 Pharmacological properties of the organic extracts of B. amyloliquefaciens MTCC 12716 and S. algae MTCC 12715 by various in vitro models

\begin{tabular}{lccc}
\hline & \multicolumn{2}{l}{ Activities $\mathrm{IC}_{90}(\mu \mathrm{g} / \mathrm{mL})$} \\
\cline { 2 - 4 } Pharmacological properties & Standard & $\begin{array}{l}\text { B. amyloliquefaciens } \\
\text { MTCC } 12716\end{array}$ & S. algae MTCC 12715 \\
\hline Antioxidant activities & & & \\
DPPH radical scavenging & $76.01^{\mathrm{a}} \pm 0.03$ & $278.19^{\mathrm{b}} \pm 0.04$ & $602.83^{\mathrm{c}} \pm 0.06$ \\
ABTS ${ }^{\mathrm{a}}$ radical scavenging & $30.76^{\mathrm{a}} \pm 0.01$ & $136.78^{\mathrm{b}} \pm 0.01$ & $483.02^{\mathrm{c}} \pm 0.09$ \\
Anti-inflammatory activities & & & \\
COX-1 inhibitory activity & $91.30^{\mathrm{a}} \pm 0.09$ & $675.36^{\mathrm{b}} \pm 0.04$ & $557.48^{\mathrm{b}} \pm 0.04$ \\
COX-2 inhibitory activity & $86.93^{\mathrm{a}} \pm 0.07$ & $29.10^{\mathrm{b}} \pm 0.07$ & $44.00^{\mathrm{c}} \pm 0.04$ \\
5-LOX inhibitory activity & $79.68^{\mathrm{a}} \pm 0.02$ & $6.06^{\mathrm{b}} \pm 0.02$ & $7.73^{\mathrm{c}} \pm 0.08$ \\
Anti-diabetic activities & & & $837.69^{\mathrm{c}} \pm 0.03$ \\
$\alpha$-amylase inhibitory activity & $312.44^{\mathrm{a}} \pm 0.01$ & $639.54^{\mathrm{b}} \pm 0.05$ & $530.43^{\mathrm{c}} \pm 0.07$ \\
$\alpha$-glucosidase inhibitory activity & $645.08^{\mathrm{a}} \pm 0.05$ & $84.00^{\mathrm{b}} \pm 0.01$ & $769.63^{\mathrm{c}} \pm 0.09$ \\
DPP-4 inhibitory activity & $7.00^{\mathrm{a}} \pm 0.03$ & $354.12^{\mathrm{b}} \pm 0.02$ & \\
Anti-hypertensive activity & & & $638.74^{\mathrm{c}} \pm 0.03$ \\
ACE inhibitory activity & $77.39^{\mathrm{a}} \pm 0.01$ & $448.57^{\mathrm{b}} \pm 0.05$ & \\
Anti-hypercholesterolemic activity & & & $74.60^{\mathrm{b}} \pm 0.01$ \\
hMGCR inhibitory activity & $0.07^{\mathrm{a}} \pm 0.06$ & $17.30^{\mathrm{b}} \pm 0.01$ & \\
\hline
\end{tabular}

The samples were analyzed in triplicates $(n=3)$ and expressed as mean \pm standard deviation. Means followed by the different superscripts $(\mathrm{a}-\mathrm{c})$ within the same row indicate significant difference $(p<0.05)$

Other notations were as described in the text

${ }^{\text {a }}$ The standard antioxidant agent was $\alpha$-tocopherol, whereas aspirin and acarbose were used as standard anti-inflammatory and anti-diabetic agent. Synthetic captopril and atorvastatin were used as standard ACE and hMGCR inhibitors, respectively 


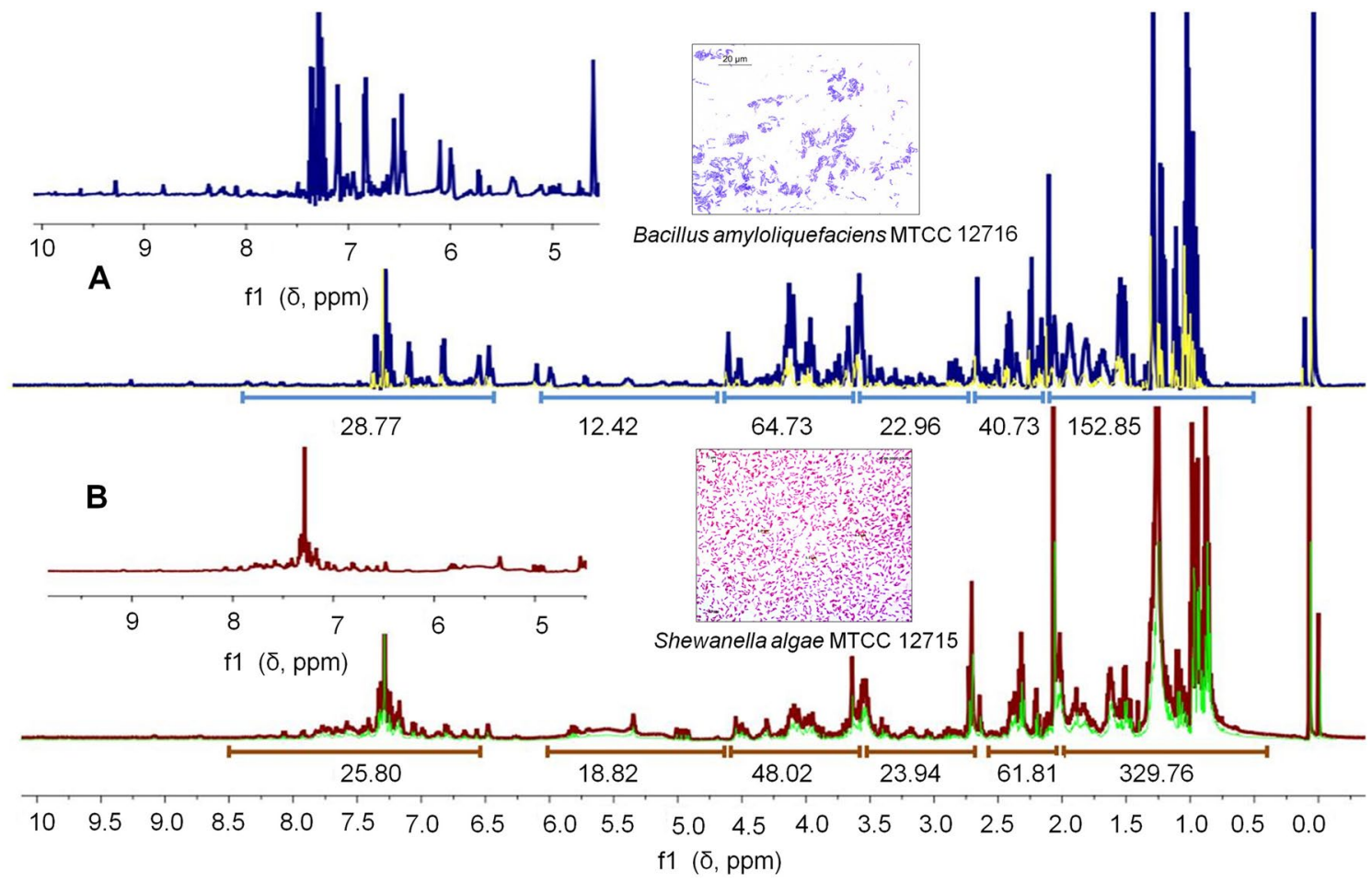

Fig. 2 The stacked plot representing the ${ }^{1} \mathrm{H}$ NMR spectra of EtOAc extracts of (A) B. amyloliquefaciens MTCC 12716 and (B) S. algae MTCC 12715

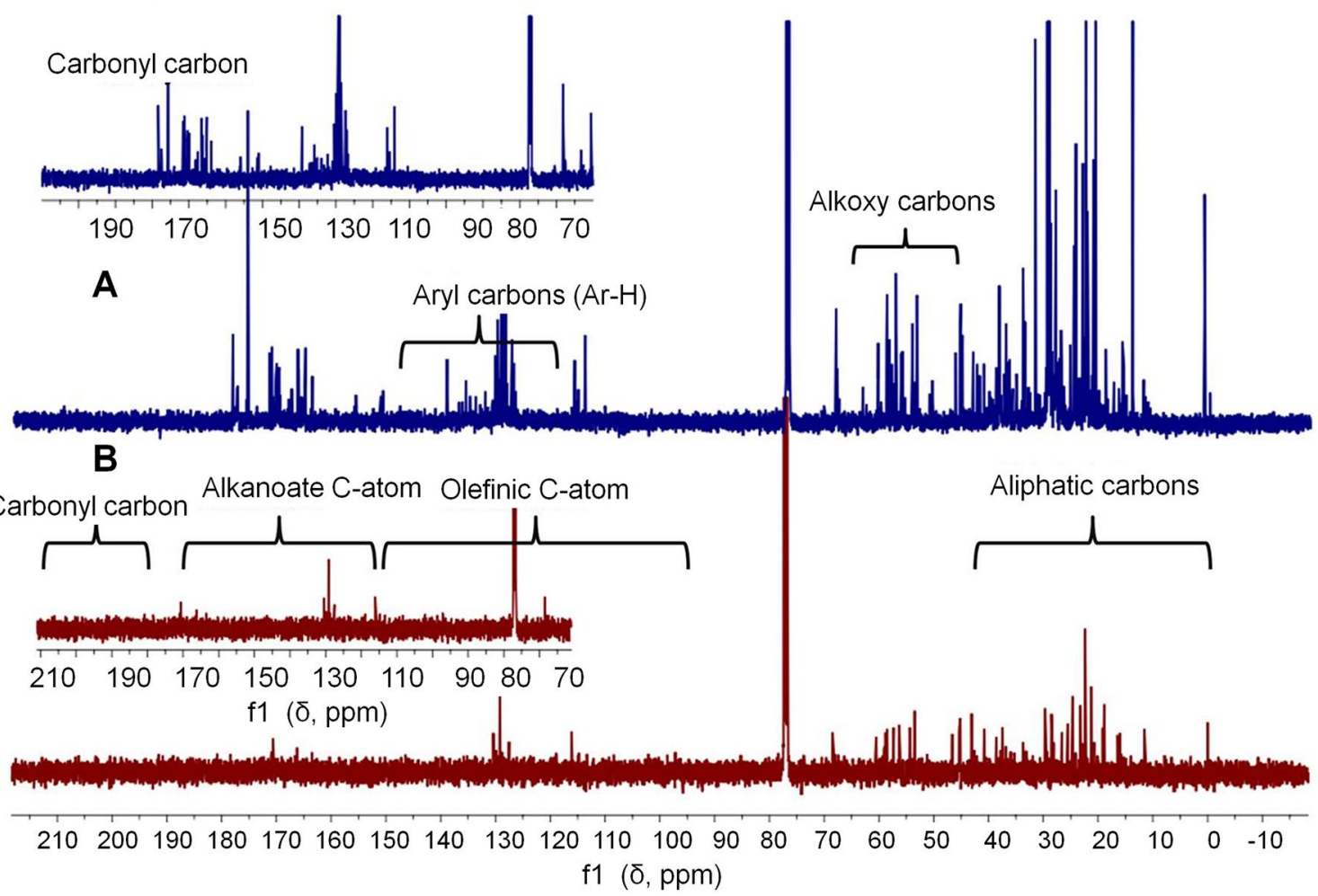

Fig. $3{ }^{13} \mathrm{C}$ NMR spectra of organic extracts of (A) B. amyloliquefaciens MTCC 12716 and (B) S. algae MTCC 12715. The chemical shift ( $\delta$ ) values were expressed in parts per million (ppm), and were referenced to the residual solvent signals of $\mathrm{CDCl}_{3}$ 
electronegative groups were apparent in that obtained from S. algae MTCC 12715 (Fig. 3). The ${ }^{13} \mathrm{C}$ olefinic carbon traces at $\delta_{\mathrm{C}} 110-140$ were displayed by the EtOAc extract of B. amyloliquefaciens MTCC 12716 and S. algae MTCC 12715, although lesser proton integrals were recorded in the ${ }^{1} \mathrm{H}$ NMR spectrum of the former, which might be attributed to the occurrences of quaternary olefinic carbons in the organic extract of B. amyloliquefaciens. The ${ }^{13} \mathrm{C}$ NMR signals due to the alkoxy $\left(-\mathrm{CH}_{2} \mathrm{O}-\right.$; $\left.\delta_{\mathrm{C}} 45-70\right)$ group and those associated with the carbons of the hydride group of alkanoates $\left\{-\mathrm{CH}_{2} \mathrm{C}(=\mathrm{O}) \mathrm{OMe}, \delta_{\mathrm{C}}\right.$ 75-80\} were found to be greater in the EtOAc extract of $S$. algae MTCC 12715 than that recorded in the extract prepared from B. amyloliquefaciens MTCC 12716.

A sharp FTIR band at $3700 \mathrm{~cm}^{-1}$ region represented free $\mathrm{O}-\mathrm{H}$ stretching in the solvent extracts of $B$. amyloliquefaciens MTCC 12716 and S. algae MTCC 12715 (Fig. S5-S6). The broad bands in the region of $3200-3600 \mathrm{~cm}^{-1}$ might represent the hydrogen bonded $\mathrm{O}-\mathrm{H}$ stretching vibration. Intense IR bands at 2928 and $2963 \mathrm{~cm}^{-1}$ might be related with the occurrences of alkyl C-H stretching and a variable frequency at 1667 and $1662 \mathrm{~cm}^{-1}$ indicated alkenyl $\mathrm{C}=\mathrm{C}$ stretching and/ or aromatic $\mathrm{C}=\mathrm{C}$ bending. Variable peaks at 1449 and $1457 \mathrm{~cm}^{-1}$ were attributed to $\mathrm{C}-\mathrm{H}$ bending of alkane groups.

\section{Principal component analysis}

The resemblances and differences between crude extracts of the two bacterial species B. amyloliquefaciens MTCC 12716 and S. algae MTCC 12715 vis-a-vis the relationships among antioxidant activity assays and different enzyme inhibitory assays were statistically analyzed via PCA (principle component analyses) (Fig. 4). PCA was performed to corroborate the antioxidant and enzyme inhibitory activities contributing to the pharmaceutical potential of the titled marine macroalgae-associated symbionts. The loadings of PC1 and PC2 (first and second principal components) were added for 50.63 and $49.37 \%$ of the variance, respectively (Fig. 4). PC1 was primarily inclined by DPPH scavenging activity of the organic extracts of B. amyloliquefaciens MTCC 12716 and S. algae MTCC 12715 (BD and SD), COX-1 and $\alpha$-glucosidase inhibitory activities (BC1, SC1 and BGL, SGL), along with hMGCR (BHMG and SHMG) and DPP-4 inhibitory activities of B. amyloliquefaciens MTCC 12716 (BDPP4), ABTS and LOX-5 (SA and SL) activities of S. algae MTCC 12715. Whereas, DPP-4 inhibitory activities of $S$. algae MTCC 12715 (SDPP4) and ABTS radical scavenging activity of B. amyloliquefaciens MTCC 12716 (BA) were mostly contributed to PC2.

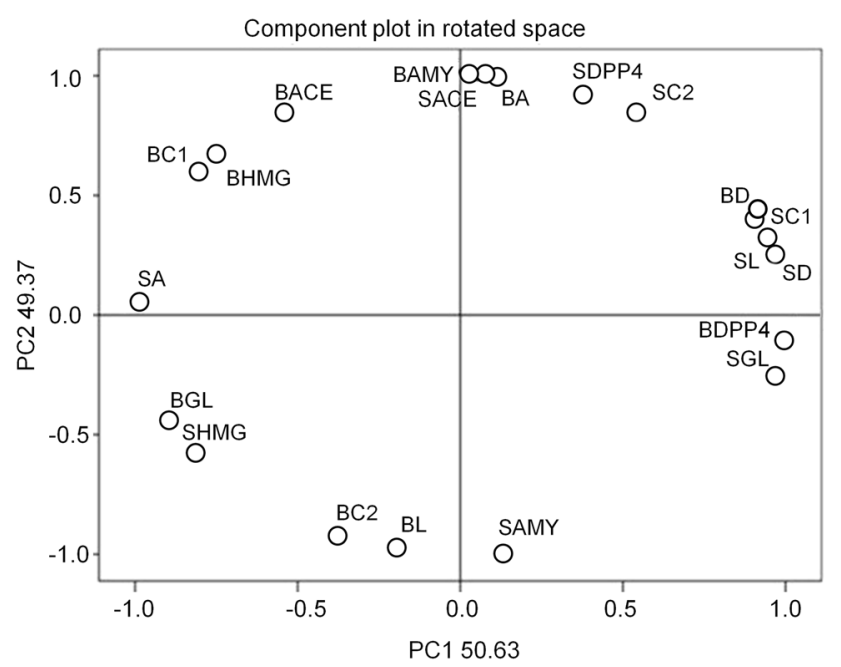

Fig. 4 Loading plot diagram (various components namely, PC-1 and PC-2 in rotated space) of antioxidant activities vis-a-vis anti-inflammatory, anti-diabetic, anti-hypertensive and anti-cholesterol activities of different organic extracts of B. amyloliquefaciens MTCC 12716 and $S$. algae MTCC 12715 . The abbreviations were explained in the text

\section{Discussions}

Marine macroalgae were reported to possess chemical defense programmes against pathogenic microorganisms in oceanic ecosystem, and the significant share of marine macroalgae-associated heterotrophic bacteria with potential bioactive properties form a valuable source of pharmaceutical applications. Presently, we have isolated 148 heterotrophic bacterial species affiliated with 7 different species of marine macroalgae belonging to the classes Chlorophyceae, Rhodophyceae, and Pheophyceae including brown algae (Sargassum myricocystum, Padina gymnospora, Turbinaria ornata), red algae (Hypnea valentiae. Kappaphycus alvarezii) and green algae (Ulva reticulata, Caulerpa racemosa). Major share (83\%) of the bioactive isolates was the representatives of $\gamma$-Proteobacteria and Firmicutes. The bacteria selected for the current study were found to possess potential antibacterial properties against clinically important pathogens (MIC $6.25-25 \mu \mathrm{g} / \mathrm{mL}$ ) E. coli, S. pyogenes, E. tarda, V. parahemolyticus, MRSA, and VRE. The strains were also examined for their pathogenic effects on blood agar plates and found to be non-pathogenic. It is widely accepted that the pathogenicity of disease-causing microorganisms could be evaluated by the production of certain extracellular products, such as hemolysins on blood agar plates (Gao et al. 2000).

Previous studies illustrated that the bacterial species in symbiotic association with eukaryotic host organisms appeared to display significantly greater bioactivities than the free-living microorganisms in the ocean and oceanic sediments (Zeng et al. 2005). The sponge-bacterial symbiotic 
association has been considered as an important model system, and there have been several studies describing marine host associated heterotrophs and their potential bioactive properties (Quevrain et al. 2014).

It was reported that, among the phylum Firmicutes, Bacillus sp. were dominantly present as heterotrophs with various marine macroalgae (Lachnit et al. 2011), and were reported for potential antibacterial and antifungal activities (Penesyan et al. 2010; Chakraborty et al. 2014). Two of the most active cultures B. amyloliquefaciens MTCC 12716 and S. algae MTCC 12715 exhibited a broad inhibition spectrum, being active against the pathogens including multidrug-resistant pathogens, such as MRSA and VRE (MIC 6.25-25 $\mu \mathrm{g} / \mathrm{mL}$ ). Notably, B. amyloliquefaciens MTCC 12716 displayed significantly greater antibacterial activity than those exhibited by S. algae MTCC 12715. Vancomycin-resistant Enterococci (VRE) and methicillin-resistant Staphylococcus aureus (MRSA) were reported to cause nosocomial infections, and have been connected with increased rates of illness and death (Amalaradjou and Venkitanarayanan 2014). In recent times, MRSA is a serious clinical problem attributed to the multidrug-resistance against variously available antibiotics. Although habitually opportunistic, many $S$. aureus strains are now recognized to be destructively pathogenic. It was assessed that Staphylococci permanently inhabit about 25\% of adults permanently, and 75-80\% transiently (Archer et al. 2011). The emergence of antibiotic-resistant bacteria led us to explore the new marine habitats for screening the production of novel anti-infective elements (Gram et al. 2010). It was found that the bacteria associated with brown alga Sargassum sp. had the antibacterial characteristic with inhibition zone ranging 3.6-4.9 mm against MRSA (Susilowati et al. 2015). Li et al. (2005) described the antibacterial activities of the solvent extract of Aspergillus sp., which was associated with red marine macroalga Hypnea saiidana, against MRSA. Heterotrophic Pseudomonas sp. isolated from Ceratodyction spongiosum (red marine macroalga) (Isnansetyo et al. 2001) was reported to inhibit the growth of MRSA. Antibacterial activity of Bacillus licheniformis in association with intertidal macroalgae Fucus serratus against MRSA and VRE were reported previously by Jamal et al. (2006). Thus, various studies on macroalgae-associated bacteria proved their antimicrobial potential against different pathogenic organisms (Penesyan et al. 2009; Chakraborty et al. 2014).

Marine microorganisms were poorly investigated for the development of drug candidates against common lifestyle disease targets, but might be of significant potential in the quest for new anti-diabetic, anti-inflammatory or anti-cholesterol drugs (Debbab et al. 2010). The marine macroalgae-associated heterotrophic bacteria B. amyloliquefaciens and $S$. algae exhibited significant antioxidative properties (Table 3). As compared to DPPH assay for determining antioxidant activity, ABTS assay was found to be more prognostic for marine bacterial extracts (Al-Zereini 2014). The greater ABTS radical quenching activities of the organic extracts from these bacteria were observed than those recorded in DPPH scavenging properties, could be attributed to the statement that ABTS measures antioxidant ability of hydrophilic and hydrophobic fractions, whereas DPPH calculates antioxidant activity only for the hydrophobic antioxidants. Antioxidants were found to reduce or terminate the oxidation process of the reductants (oxidizable components), through free radical quenching and decreasing oxidative stress (disproportionate generation of reactive oxygen species and reactive nitrogen species) (Scott 2004). The resultant oxidation of various biomolecules might potentially lead to the development of various oxidative stress-induced disorders, such as hypertension, type- 2 diabetes and arteriosclerotic vascular disease (Scott 2004). There has been increasing evidence that free radical-induced damage could play an important role in the onset of type-2 diabetes and impaired glucose tolerance (Wright et al. 2006) along with vascular injury and organ dysfunction due to hypertension (Elahi and Matata 2006).

B. amyloliquefaciens MTCC 12716 and S. algae MTCC 12715 showing potential antibacterial activities against clinically important pathogens were selected to evaluate their pharmacological properties associated with hypertension, inflammation, diabetes and hypercholesterolemia. Notably, Angiotensin Converting Enzyme (ACE) inhibitors prevent the vasoconstricting octapeptide angiotensin II conversion leading to the relaxation of blood vessels resulting in a lower blood pressure (Dostal and Baker 1999). ACE inhibitors can be the potential pharmacophores for the management of hypertensive disorders. However, the adverse reactions of synthetic drugs (Atkinson and Robertson 1979) have contributed to a greater interest in searching for natural ACE inhibitors. The organic extract of B. amyloliquefaciens MTCC 12716 displayed significantly greater ACE inhibitory activity $\left(\mathrm{IC}_{90} 448 \mu \mathrm{g} / \mathrm{mL}\right)$ than that exhibited by $S$. algae $\left(\mathrm{IC}_{90} 663 \mu \mathrm{g} / \mathrm{mL}\right.$ ). There were reports that the microbial peptides and secondary metabolites of actinomycetes (Manthey and Reuter1989) were potent ACE inhibitors.

The $\alpha$-amylase and $\alpha$-glucosidase were reported to involve in the catabolism of ingested sugar moieties and their inhibition slows down the intake of glucose by acting as a promising approach in the treatment of type- 2 diabetes (Tabatabaei-Malazy et al. 2015). The organic extract of B. amyloliquefaciens MTCC 12716 displayed significantly greater $\alpha$-glucosidase inhibitory activity $\left(\mathrm{IC}_{90} 84 \mu \mathrm{g} / \mathrm{mL}\right)$ than that exhibited by $S$. algae $\left(\mathrm{IC}_{90}>600 \mu \mathrm{g} / \mathrm{mL}\right)$ and acarbose $\left(\mathrm{IC}_{90} 645 \mu \mathrm{g} / \mathrm{mL}\right)$, the commonly prescribed drug for type-2 diabetes. Pandey et al. (2013) found that the marine sponge Aka coralliphaga associated heterotrophic Proteobacteria and Firmicutes, developed various glucosidase inhibitors. 
The cyclooxygenase isoforms (constitutive COX-1 and inducible COX-2) and lipoxygenase (5-LOX) enzymes were reported to catalyze the synthesis of inflammatory lipid mediators, such as prostaglandins and leukotrienes (Charlier and Michaux 2003). Dual 5-LOX/COX-2 inhibitors are prospective anti-inflammatory candidates as they function by impeding the development of inflammatory prostaglandins and leukotrienes. Such combined inhibition of 5-LOX/COX-2 avoids the major drawbacks associated with COX-1 inhibitors and protects the gastrointestinal mucosa (Charlier and Michaux 2003). The organic extract of B. amyloliquefaciens MTCC 12716 displayed significantly greater COX-2 and 5-LOX inhibitory activities $\left(\mathrm{IC}_{90} 29\right.$ and $6.06 \mu \mathrm{g} / \mathrm{mL}$, respectively) than those exhibited by $S$. algae ( $\mathrm{IC}_{90} 44$ and $7.73 \mu \mathrm{g} / \mathrm{mL}$, respectively). Significant anti-inflammatory activities of marine symbiotic bacterial crude extracts were reported earlier by Kurian et al. (2015).

Hyperlipidemia (elevated cholesterol or triglyceride) has been recognized as one of the most important causes of atherosclerosis-related disorders, such as coronary heart disease and peripheral vascular disease. HMG-CoA reductase (hMGCR) was found to be the pivotal enzyme in the rate determining step of sterol biosynthesis and the statinlike drugs are inhibitors of human hMGCR (Maciejak et al. 2013). The organic extract of B. amyloliquefaciens MTCC 12716 displayed significantly greater hMGCR inhibitory activities ( $\mathrm{IC}_{90} 17 \mu \mathrm{g} / \mathrm{mL}$, respectively) than that exhibited by $S$. algae $\left(\mathrm{IC}_{90} 75 \mu \mathrm{g} / \mathrm{mL}\right)$.

The greater proton integral due to saturated hydrocarbons (at $\delta_{\mathrm{H}} 0.1-2.0$ ) in ${ }^{1} \mathrm{H}$ NMR spectrum of the organic extract of S. algae MTCC 12715 were attributed to associate with fatty acyl esters or fatty acid derivatives, phospholipids, sterols, or glycolipids. The presence of fatty acyl analogs could be corroborated by the higher proton integrals of the $S$. algae MTCC 12715 extract $\left(\sum \mathrm{H} \sim 24\right)$ at $\delta_{\mathrm{H}} 2-3.5$ (attributed to the presence of acetyl and $-\mathrm{OCH}_{3}$ groups). Likewise, the higher proton integrals attributed to the acetyl or allylic functionalities $\left(\sum \mathrm{H}>60\right)$ in the extract prepared from S. algae MTCC 12715 , and comparatively weaker proton integrals at this position for B. amyloliquefaciens MTCC 12716 extract $\left(\sum \mathrm{H}<50\right)$ appropriately supported these assignments. The greater proton integrals of the $S$. algae MTCC 12715 organic extract, at the characteristic olefinic region $\left(\delta_{\mathrm{H}} 4.5-6\right)$ could thus be correlated with the occurrences of fatty acid derivatives with mono- and/or poly-unsaturations. Since the fatty acid derivatives were considered as the structural components of the organisms and did not attribute to the bioactive potential, the greater pharmacological properties of the EtOAc extract of B. amyloliquefaciens MTCC 12716 could thus be rationalized. Bioactive polysaccharides were found to occupy a predominant role in determining the pharmacological properties of the microorganisms (Rehm 2010), and greater proton integrals $\left(\sum \mathrm{H} \sim 65\right)$ at the anomeric region of the ${ }^{1} \mathrm{H}$ NMR spectrum $\left(\delta_{\mathrm{H}} 3.6-4.5\right)$ of the EtOAc extract of B. amyloliquefaciens MTCC 12716, than that obtained from S. algae MTCC 12715 extract $\left(\sum \mathrm{H}<50\right)$ attributed to the possible functional role of polysaccharide analogs in determining the bioactive properties of the former. The greater ${ }^{1} \mathrm{H}$ NMR proton integral $\left(\sum \mathrm{H} \sim 29\right)$ due to the aryl signals $\left(\delta_{\mathrm{H}} 6.6-8.6\right)$, in the solvent extracts of B. amyloliquefaciens MTCC 12716 might be associated with the presence of aromatic centers, which were found to possess a significant role in determining the pharmacological properties of the said bacterium.

In this study, the organic extract of B. amyloliquefaciens MTCC 12716 was found to possess greater number of electronegative carbonyl and aryl carbons in the downfield space of the ${ }^{13} \mathrm{C}$ NMR spectrum $\left(\delta_{\mathrm{C}} 180-200\right.$ and $140-160$, respectively) than that prepared from S. algae MTCC 12715 , which apparently signified the presence of electron-rich centered bioactive principles of the former. The EtOAc extract of $S$. algae and B. amyloliquefaciens exhibited ${ }^{13} \mathrm{C}$ NMR olefinic functionalities at the characteristic region of $\delta_{\mathrm{C}}$ $110-140$, although lower proton integrals in the ${ }^{1} \mathrm{H}$ NMR spectrum of the latter assigned to the occurrences of quaternary olefinic carbons. The signal intensity and the number of ${ }^{13} \mathrm{C}$ carbon atoms due to the alkoxy $\left(\delta_{\mathrm{C}} 45-70\right)$ carbon and those associated with alkyl alkanoate groups $\left(\delta_{\mathrm{C}} 75-80\right)$ were lesser in the organic extract of $B$. amyloliquefaciens MTCC 12716 than that from S. algae MTCC 12715. These results appropriately corroborated the presence of fatty acyl analogs (along with phospholipids), which were reported as the structural components of the bacterium, and possessed meager functional role towards the bioactivities and pharmacological properties, due to the S. algae MTCC 12715 extract.

Marine Bacillus species was reported to produce promising bioactive metabolites, such as aromatic polyketides (with multiple carbonyl groups bearing aromatic functionalities), bacteriocins, and other unique compounds of potential clinical significance (Armstrong et al. 2001). In this study, PCA were performed on the basis of the covariance structure of the data, which convert the means across the originally measured numerical information into new variables, the principal components (PCs), which were orthogonal (Maisuthisakul et al. 2008). PCA appropriately corroborated the antioxidant vis-a-vis enzyme inhibitory activities contributing to the various pharmaceutical potential of the studied marine macroalgaeassociated symbionts, and revealed the loadings of PC1 and PC2 for the studied bioactivities. The organic extract of $B$. amyloliquefaciens displayed significantly greater antioxidative properties $\left(\mathrm{IC}_{90}<1 \mathrm{mg} / \mathrm{mL}\right)$ and the activities showed considerable positive correlation $\left(r^{2}>0.8\right.$, $P<0.05)$ with the inhibitory activities against ACE-1, 
pro-inflammatory biocatalysts, DPP-4 and hMGCR, which were associated with hypertension, inflammation, diabetes, and hypercholesterolemia, respectively. Specifically, the loadings of PC1 were also inclined towards the positive correlation between the bioactivities, which implied that the functional groups present in the extract prepared from B. amyloliquefaciens MTCC 12716 were endowed with the potential pharmacological properties with regard to antioxidant (DPPH scavenging), antiinflammatory (anti-cyclooxygenase), anti-diabetic (DPP-4 inhibitory), and anti-hypercholesterolemic (hMGCR inhibitory) activities. These results appropriately revealed the promising therapeutic potential of marine macroalgaassociated heterotrophic bacterium B. amyloliquefaciens MTCC 12716.

The present work revealed pharmaceutical potentials of the organic extracts derived from the heterotrophic bacteria in association with marine macroalgae. The heterotrophs predominantly belonging to $\gamma$-Proteobacteria and Firmicutes comprised greater than $50 \%$ of culturable bacteria, and were found to possess potential antibacterial properties (MIC $6.25-25 \mu \mathrm{g} / \mathrm{mL}$ ) against the clinically important pathogens including MRSA and VRE. Heterotrophic B. amyloliquefaciens MTCC 12716 and S. algae MTCC 12715 displayed potential anti-infective properties and their ethyl acetate extracts were assayed for their pharmacological properties using various in vitro models. The organic extract of B. amyloliquefaciens MTCC 12716 displayed significantly greater ACE-1, pro-inflammatory COX-2/5-LOX, $\alpha$ glucosidase/DPP-4 and hMGCR-inhibitory activities associated with hypertension, inflammation, diabetes, and hypercholesterolemia, respectively. ${ }^{1} \mathrm{H}$ NMR fingerprint analyses of the prominent functional groups in the organicextracts of the symbionts revealed the presence of greater proton integral of the same derived from $B$. amyloliquefaciens MTCC 12716 at the downfield region of $\delta_{\mathrm{H}} 2.0-3.5$ and 4.5-8.5, which could be responsible for the potential bioactivities. The heterotrophic marine macroalgae-associated B. amyloliquefaciens MTCC 12716 might, therefore, serve as a potential therapeutic candidate to develop microbial products with wide pharmaceutical and biotechnological applications.

Acknowledgements This work was supported by funding under Kerala State Council for Science, Technology and Environment (Grant No. 040/FSHP-LSS/2014/KSCSTE). The authors are thankful to Indian Council of Agricultural Research (ICAR), New Delhi for providing facilities to carry out the work. The authors gratefully thank the Director, National Centre for Aquatic Animal Health of Cochin University of Science and Technology, Cochin to provide us with the pathogenic organisms. The authors thank the Director, Central Marine Fisheries Research Institute and Dean, Faculty of Marine Sciences, Lakeside Campus, Cochin University of Science and Technology for support. Thanks are due to the Head, Marine Biotechnology Division, Central Marine Fisheries Research Institute for facilitating the research activity.

\section{Compliance with ethical standards}

Research involving human or animal participants This article does not contain any studies with human participants or animals performed by any of the authors.

Conflict of interest No potential conflict of interest was reported by the authors.

\section{References}

Ademiluyi AO, Oboh G (2013) Soybean phenolic-rich extracts inhibit key-enzymes linked to type- 2 diabetes ( $\alpha$-amylase and $\alpha$-glucosidase) and hypertension (angiotensin-I converting enzyme) in-vitro. Exp Toxicol Pathol 65:305-309

Ali AIB, Bour ME, Ktari L, Bolhuis H, Ahmed M, Boudabbous A, Stal LJ (2012) Jania rubens-associated bacteria: molecular identification and antimicrobial activity. J Appl Phycol 24:525-534

Al-Zereini WA (2014) Bioactive crude extracts from four bacterial isolates of marine sediments from Red Sea, Gulf of Aqaba, Jordan. Jordan J Biol Sci 7:133-137

Amalaradjou MAR, Venkitanarayanan K (2014) Antibiofilm effect of octenidine hydrochloride on Staphylococcus aureus, MRSA and VRSA. Pathogens 3:404-416

Archer NK, Mazaitis MJ, Costerton JW (2011) Staphylococcus aureus biofilms: properties, regulation, and roles in human disease. Virulence 2:445-459

Armstrong E, Yan L, Boyd KG, Wright CP, Burgess JG (2001) The symbiotic role of marine microbes on living surfaces. Hydrobiol 461:37-40

Atkinson AB, Robertson JI (1979) Captopril in the treatment of clinical hypertension and cardiac failure. Lancet 2:836-839

Balouiri M, Sadiki M, Ibnsouda SK (2016) Methods for in vitro evaluating antimicrobial activity: a review. J Pharm Anal 6:71-79

Baylac S, Racine P (2003) Inhibition of 5-lipoxygenase by essential oils and other natural fragrant extracts. Int J Aromather 13:138-142

Brand-Williams W, Cuvelier M, Berset C (1995) Use of free radical method to evaluate antioxidant activity. LWT - Food Sci Technol 28:25-30

Chakraborty K, Thilakan B, Raola VK (2014) Polyketide family of novel antibacterial 7-O-methyl-5'-hydroxy-3'-heptenoate macrolactin from seaweed-associated Bacillus subtilis MTCC 10403. J Agric Food Chem 62:12194-12208

Chakraborty K, Thilakan B, Raola VK (2017a) Antimicrobial polyketide furanoterpenoids from seaweed-associated heterotrophic bacterium Bacillus subtilis MTCC 10403. Phytochemistry 142:112-125

Chakraborty K, Thilakan B, Chakraborty RD, Raola VK, Joy M (2017b) $O$-heterocyclic derivatives with antibacterial properties from marine bacterium Bacillus subtilis associated with seaweed, Sargassum myriocystum. Appl Microbiol Biotechnol 101:569-583

Charlier C, Michaux C (2003) Dual inhibition of cyclooxygenase-2 (COX-2) and 5-lipoxygenase (5-LOX) as a new strategy to provide safer non-steroidal anti-inflammatory drugs. Eur J Med Chem 38:645-659

Davidson BS (1995) New dimensions in natural products research: cultured marine microorganisms. Curr Opin Biotechnol 6:284-291

Debbab A, Aly AH, Lin WH, Proksch P (2010) Bioactive compounds from marine bacteria and fungi. Microb Biotechnol 5:544-563

Dostal DE, Baker KM (1999) The cardiac renin-angiotensin system: conceptual, or a regulator of cardiac function? Circ Res $85: 643-650$ 
Elahi MM, Matata BM (2006) Free radicals in blood: evolving concepts in the mechanism of ischemic heart disease. Arch Biochem Biophys 450:78-88

Gao DQ, Huang XQ, Lu CP, Wu SY (2000) Characteristic of the hemolysin of Edwardsiella tarda. Chin J Zoon 16:53-55

Gram L, Melchiorsen J, Bruhn JB (2010) Antibacterial activity of marine culturable bacteria collected from a global sampling of ocean surface waters and surface swabs of marine organisms. Mar Biotechnol 12:439-451

Hollants J, Leliaert F, Clerck OD, Willems A (2012) What we can learn from sushi: a review on seaweed-bacterial associations. FEMS Microbiol Ecol 83:1-16

Holmquist B, Bunning P, Riordan JF (1979) A continuous spectrophotometric assay for angiotensin converting enzyme. Anal Biochem 95:540-548

Isnansetyo A, Horikawa M, Kamei Y (2001) In vitro anti-methicillinresistant Staphylococcus aureus activity of 2,4- diacetylphloroglucinol produced by Pseudomonas sp. AMSN isolated from a marine alga. J Antimicrob Chemother 47:724-725

Jamal MT, Morris PC, Hansen R, Jamieson DJ, Burgess GJ, Austinm B (2006) Recovery and characterization of a 30.7-kDa protein from Bacillus licheniformis associated with inhibitory activity against methicillin-resistant Staphylococcus aureus, vancomycinresistant Enterococci, and Listeria monocytogenes. Mar Biotechnol 8:587-592

Kennedy J, Baker P, Piper C, Cotter PD, Walsh M, Mooij MJ, Bourke MB, Rea MC, O'Connor PM, Ross RP, Hill C, O'Gara F, Marchesi JR, Dobson AD (2009) Isolation and analysis of bacteria with antimicrobial activities from the marine sponge Haliclona simulans collected from Irish waters. Mar Biotechnol 11:384-396

Krieg NR, Holt JG (1984) Bergey's manual of systematic bacteriology. Williams and Wilkins Co., Baltimore

Lachnit T, Meske D, Wahl M, Harder T, Schmitz R (2011) Epibacterial community patterns on marine macroalgae are host-specific but temporally variable. Environ Microbiol 13:655-665

Larsen LN, Dahl E, Bremer J (1996) Peroxidative oxidation of leucodichlorofluorescein by prostaglandin $\mathrm{H}$ synthase in prostaglandin biosynthesis from polyunsaturated fatty acids. Biochim Biophys Acta 1299:47-53

Li JW, Vederas JC (2009) Drug discovery and natural products: end of an era or an endless frontier? Science 325:161-165

Li G-Y, Li B-G, Yang T, Yin J-H, Qi H-Y, Liu G-Y, Zhang G-L (2005) Sesterterpenoids, terretonins A-D, and an alkaloid, asterrelenin, from Aspergillus terreus. J Nat Prod 68:1243-1246

Maciejak A, Leszczynska A, Warchol I, Gora M, Kaminska J, Plochocka D, Kapcinska MW, Tulacz D, Siedlecka J, Swiezewska E, Sojka M, Danikiewicz W, Odolczyk N, Szkopinska A, Sygitowicz G, Burzynska B (2013) The effects of statins on the mevalonic acid pathway in recombinant yeast strains expressing human $\mathrm{HMG-CoA}$ reductase. BMC Biotechnol 13:68

Maisuthisakul P, Pasuk S, Ritthiruangdej P (2008) Relationship between antioxidant properties and chemical composition of some Thai plants. J Food Compost Anal 21:229-240

Tabatabaei-Malazy O, Larijani B, Abdollahi M (2015) Targeting metabolic disorders by natural products. J Diabetes Metab Disord 14:57

Manthey A, Reuter G (1989) Microbial synthesis of metabolites with antihypertensive activity: aspects of fermentation derived inhibitors of angiotensin-converting enzyme ACE. J Basic Microbiol 29:623-639

Molinski TF, Dalisay DS, Lievens SL, Saludes JP (2009) Drug development from marine natural products. Nat Rev Drug Discov 8:69-85

National Research Council (1999) From monsoons to microbes: understanding the ocean's role in human health. The National Academies Press, Washington, DC. https://doi.org/10.17226/6368

Kurian NK, Nair HP, Bhat HG (2015) Evaluation of anti-inflammatory property of melanin from marine Bacillus spp. BTCZ31. Asian J Pharm Clin Res 8:251-255
Okamura M, Shimazaki K, Nakata T, Chida N, Miyatake T, Maemoku H, Tsutsumi H, Nakamura T, Yamaguchi C, Ogawa M (1992) Submarine active faults in the northwestern part of Beppu Bay, Japan-On a new technique for submarine active fault survey. Mem Geol Soc Jpn 40:65-74

Pandey S, Sree A, Dash SS, Sethi DP, Chowdhury L (2013) Diversity of marine bacteria producing beta-glucosidase inhibitors. Microb Cell Fact 12:35

Paul VJ, Ritson-Williams R, Sharp K (2011) Marine chemical ecology in benthic environments. Nat Prod Rep 28:345-388

Penesyan A, Marshall-Jones Z, Holmstrom C, Kjelleberg S, Egan S (2009) Antimicrobial activity. FEMS Microbiol Ecol 69:113-124

Penesyan A, Kjelleberg S, Egan S (2010) Development of novel drugs from marine surface associated microorganisms. Mar Drugs 8:438-459

Quevrain E, Roue M, Bourguet-Kondracki IM (2014) Assessing the potential bacterial origin of the chemical diversity in calcareous sponges. J Mar Sci Tech 22:36-49

Re R, Pellegrini N, Proteggente A, Pannala A, Yang M, Rice Evans C (1999) Antioxidant activity applying an improved ABTS radical cation decolorization assay. Free Radic Biol Med 26:1231-1237

Rehm BHA (2010) Bacterial polymers: biosynthesis, modifications and applications. Nat Rev Microbiol 8:578-592

Scott J (2004) Pathophysiology and biochemistry of cardiovascular disease. Curr Opin Genet Dev 14:271-279

Susilowati R, Sabdono A, Widowati I (2015) Isolation and characterization of bacteria associated with brown algae Sargassum spp. from Panjang Island and their antibacterial activities. Procedia Environ Sci 23:240-246

Tabbene O, Gharbi D, Slimene IB, Elkahoui S, Alfeddy MN, Cosette P, Mangoni ML, Jouenne T, Limam F (2012) Antioxidative and DNA protective effects of bacillomycin D-like lipopeptides produced by b-38 strain. Appl Biochem Biotechnol 168:2245-2256

Tang JS, Zhao F, Gao H, Dai Y, Yao ZH, Hong K, Li J, Ye WC, Yao XS (2010) Characterization and online detection of surfactin isomers based on HPLC-MS(n) analyses and their inhibitory effects on the overproduction of nitric oxide and the release of TNF- $\alpha$ and IL- 6 in LPS induced macrophages. Mar Drugs 8:2605-2618

Thilakan B, Chakraboty K, Chakraborty RD (2016) Antimicrobial properties of cultivable bacteria associated with seaweeds in Gulf of Mannar of South East Coast of India. Can J Microbiol 62:668-681

Turick CE, Caccavo F Jr, Tisa LS (2008) Pyomelanin is produced by Shewanella algae $\mathrm{BrY}$ and affected by exogenous iron. Can J Microbiol 54:334-339

Webster NS, Taylor MW (2012) Marine sponges and their microbial symbionts: love and other relationships. Environ Microbiol 14:335-346

Weisburg WG, Barns SM, Pelletier DA, Lane DJ (1991) 16S ribosomal DNA amplification for phylogenetic study. J Bacteriol 173:697-703

Wiese J, Thiel V, Nagel K, Staufenberger T, Imhoff JF (2009) Diversity of antibiotic-active bacteria associated with the brown alga Laminaria saccharina from the Baltic Sea. Mar Biotechnol 11:287-300

Wright E Jr, Scism-Bacon JL, Glass LC (2006) Oxidative stress in type 2 diabetes: the role of fasting and postprandial glycemia. Int J Clin Pract 60:308-314

Zeng L, Han X, Chen HM, Lin W, Yan XJ (2005) Marine bacteria associated with marine macro organisms: the potential antimicrobial resources. Ann Microbiol 55:119-124

Zhu K, Ding X, Julotok M, Wilkinson BJ (2005) Exogenous isoleucine and fatty acid shortening ensure the high content of anteiso-C15:0 fatty acid required for low-temperature growth of Listeria monocytogenes. Appl Environ Microbiol 71:8002-8007 